\title{
Proposing possibilities for an international debate in occupational therapy
}

Occupation is now recognised as a human need and inextricably linked to the social determinants of health. From its beginnings where it was considered merely a concept of diversional activity, occupational engagement and its many facets is now embedded in global health delivery (WORLD..., 2019). The focus on community provision reflects the contextual philosophy of occupational therapy. The individualised targeting of care reflects the person centred philosophy and the focus on self management and readiness for change reflects the empowerment which is core to our profession. It is therefore of no surprise to the global profession of occupational therapy that health and social care determinants are now speaking our professions language.

Between countries, we share the same philosophical assumptions but our translation of the delivery of our practice varies. We are therefore a global profession with similar values and beliefs but with differences in its political, cultural, historical background, and interpretation. Such differences have been recently echoed by Marilyn Pattison, President of World Federation of Occupational Therapists (WFOT). In her editorial she compares a country with a dominant medical model to a country with a dominant social model of disability. She recognises the success of each model of delivery for the service users resident in that country and the flexibility which the occupational therapy philosophy enables. She recognises that occupational therapists have adapted to each countries health system (PATTISON, 2018). These adaptations were likely aided by the common theories that guide our occupational therapy practice.

The effects of the Bologna Declaration, signed in 1999 by the ministers of education of 45 European countries, point to the establishment of common standards and guidelines that can give parameters to the global processes of qualification and unification of curricula, double diplomacy, exchanges and cooperation among universities, international student and professional mobility (MANGIA; BREGALDA, 2018). In Occupational Therapy, this process has been coordinated by European institutions and organizations such as the Council of Occupational Therapists for the European Countries (COTEC) and the European Network of Occupational Therapy in Higher Education (ENOTHE). It seeks to build flexible and quality training proposals that are comparable across countries and capable of responding to global needs and changes. It also aims to develop local and international partnerships that promote and give visibility to Occupational Therapy (COUNCIL..., 2008; MANGIA; BREGALDA, 2018). The World Federation of Occupational Therapists similarly provides a key function in ensuring quality pre-registration occupational therapy programmes globally by producing Minimum Standards for the Education of Occupational Therapists and an important accreditation function (WORLD...., 2018a).

The three authors of this editorial have had the privilege to critically analyse each others occupational therapy delivery in the context of their country's' health and social care provision (CAREY; CRUZ; LAYNE, 2019). Brazil, the United States of America-USA, and the United Kingdom have significant differences in their political structure and hence significant differences in their organisation of health, education, and social care provision. There are therefore differences in the translation of the occupational therapy philosophy.

Practice differences are evident in the focus of employment settings for occupational therapy. Whilst a high percentage of occupational therapists are employed within mental health in the UK and Brazil, it is significantly less so in the USA, whereas paediatrics is significantly higher an employment setting in the United States of America than for the UK. Occupational therapy in the United States is historically rooted in mental health, however currently less than $3 \%$ of occupational therapists work in mental health in the USA (AMERICAN..., 2015). Over half of Occupational Therapists in the USA work within the primarily private medical model (AMERICAN..., 2015). Whereas in Brazil and UK it is more a health delivery (DRUMMOND; CRUZ, 2018). Particularly in Brazil, occupational therapists are becoming 
more engaged in addressing issues of social injustice through the field of social care and education to promote social changes. These occupational therapists understand occupation as a collective, influencing life through historical and social contexts (MUNGUBA; MALFITANO; LOPES, 2018). Galheigo et al. (2018) defines this proposed direction as a movement towards fields of knowledge and intervention of occupational therapy based in the sociopolitical context, the theoretical-conceptual discussion, and the goal for emancipatory actions.

In education there are significant differences in the entry level qualification and also the regulation of assistants. Education standards vary from country to country (WESCOTT; WHITCOMBE, 2003) and whilst WFOT provides overarching standards, especially in terms of placement delivery, there remains vast pre-registration differences globally (WORLD..., 2018b). The United States of America in April 2019 has decided to maintain both masters and doctoral level entry whilst Brazil and UK maintain the degree level as a minimum. The regulation of occupational therapy assistants is established practice in the USA requiring an associate's degree and licensure, whilst in the UK remain steadfast in the flexible delivery of assistants in the professional delivery. In Brazil there were occupational therapy assistants in the beginning of the profession mainly in psychiatric hospitals. Some of them remain employed doing this work in a few hospitals, however, this position tend to be extinct.

Research in Occupational Therapy in Brazil started during the seventies when the first lectures started their masters and later doctorate degree (CRUZ, 2019).The majority of research in the area comes from public universities. There is one $\mathrm{PhD}$ Program and two masters specific in Occupational Therapy in Brazil. The Brazilian Journal of Occupational Therapy is the only one indexed internationally in Scopus and Web of Science research database (LOPES; CRUZ; MALFITANO, 2017).

The UK has a strong tradition in occupational therapy research but wants to ensure increased embedding of research activity and therefore Royal College of Occupational Therapists is facilitating this by presently constructing the Vision, Strategy and Action Plan for Research and Development (ROYAL..., 2019). The British Journal of Occupational Therapy started publishing research articles in 1960's but these were small scale, local projects (CRAIK, 2018) and it has now developed to a strategy of internationally relevant research and reviews. Craik (2018) attributes such a development to the introduction of degree qualifications in United Kingdom in 1990's. The profession in United Kingdom is now seeing a significant growth in occupational therapists gaining post registration $\mathrm{PhD}$ in occupational therapy relevant studies.

The American Occupational Therapy Association was founded in 1917. The first OT journal published in the USA was the Archives of Occupational Therapy in 1922 (AMERICAN..., 2017). Articles for this journal were primarily written by medical doctors and were mostly descriptive. The American Journal of Occupational Therapy, a peer-reviewed research journal dedicated to examining the efficacy of occupational therapy was first published 72 years ago in 1947. The American Occupational Therapy Foundation was established in 1965 to increase the knowledge and science of occupational therapy (AMERICAN..., 2017). In the 1960s and 1970s, OT literature primarily focused on pediatric and psychiatric occupational therapy, with emerging articles regarding geriatric OT in the 1970s (DIRETTE, 2017). In the 1980s with increased focus on measurement validity and reliability, there was a shift in practice to the medical model (DIRETTE, 2017). In the 1990s there was an increase in qualitative and quantitative research by OTs with doctorate degrees and resulting improved evidence based practice (DIRETTE, 2017). In 2007 post baccalaureate entry level was mandatory for occupational therapists in the USA and standards were written for an entry level doctorate (AMERICAN..., 2017). In 2012, The Open Journal of Occupational Therapy was first published and the first publication of the Journal of Occupational Therapy Education was in 2017 in the USA. One hundred years worth of effort and dedication by occupational therapy practitioners, educators, and researchers was validated by an independent study which revealed that occupational therapy was the only spending category in which additional spending resulted in a decrease in hospital readmissions increasing the quality of life for the clients that we serve and reducing cost to healthcare payer sources (ROGERS et al., 2017).

Whilst such similarities and differences are recognised, the question is whether such critical analysis is important for the development of the profession. Globalisation is considered a concept of an ever decreasing world (GIDDENS, 2001) and social media has achieved a transparency and connectedness to each others practice. Lee (2004, p. 158) described global health as “[...] complex patterns of interconnectedness [...]". 
Does such interconnective communication have the potential to improve the quality of each countries occupational therapy delivery?

The three authors have gained much in their understanding of practice, education and research from their collaboration - an understanding of others' perspectives of occupational therapy priorities, a respect for differences in emphasis and a more steadfast understanding of the occupational therapy philosophy which binds us.

Recommendations, from our experience, for learning through globalised occupational therapy are: For students and practitioners:

1. Seize opportunities for social networking with peers globally;

2. Collaborate with others internationally to discuss the benefits and challenges of service provision in their respective countries;

3. Discuss global solutions to healthcare challenges;

4. Consider opportunities for overseas placement and secondment practitioner opportunities;

5. Initiate practitioner networking with similar specialisms globally.

For Leaders and educators:

1. Produce partnerships which enable coproductive teaching and learning delivery for tutors and students;

2. Increase opportunities for visiting professorships in Higher Education;

3. Create social networking opportunities to encourage shared learning opportunities;

4. Share best practice through specialist area blog delivery;

5. Utilise case study approach as vehicle for understanding similarities and differences of provision;

6. Place value on global secondment opportunities;

7. Get engaged in research projects to understand how OT Philosophy is presented in different countries;

8. Initiate mentorship schemes internationally rather than solely nationally.

In conclusion, appreciating the similarities and respecting the differences provides us with a depth of understanding to which we can enhance our own countries occupational therapy delivery.

\title{
Helen Carey ${ }^{\mathrm{a}}$ (D), Daniel Marinho Cezar da Cruz ${ }^{\mathrm{ab}}$ (D), Kelly Layne ${ }^{(1 D}$
}

\author{
${ }^{a}$ Wrexham Glyndwr University, Wrexham, United Kingdom. \\ bUniversidade Federal de São Carlos - UFSCar, São Carlos, SP, Brasil. \\ 'University of St. Augustine for Health Sciences, St. Augustine, Florida, United States of America.
}

\section{References}

AMERICAN OCCUPATIONAL THERAPY ASSOCIATION - AOTA. Occupational Therapy Code of ethics. American Journal Occupational Therapy, Bethesda, v. 69, p. 6913410030p1-6913410030p8, 2015. Supplement. https://doi. org/10.5014/ajot.2015.696S03.

AMERICAN OCCUPATIONAL THERAPY ASSOCIATION - AOTA. Occupational Therapy Celebrating 100. Important events. 2017. Available from: <http://www.otcentennial.org/moments/ot-practice-first-issue-1995-galleryof-covers>. Access on: 1 july 2019. 
CAREY, H.; CRUZ, D. M. C.; LAYNE, K. Does globalisation matter to practising occupational therapists? Learning internationally to improve practice. In: ROYAL COLLEGE OF OCCUPATIONAL THERAPISTS ANNUAL CONFERENCE, 2019, Birmingham. Proceedings... London: Royal College of Occupational Therapists, 2019. p. 94.

COUNCIL OF OCCUPATIONAL THERAPISTS FOR THE EUROPEAN COUNTRIES - COTEC. EUROPEAN NETWORK OF OCCUPATIONAL THERAPY HIGHER EDUCATION - ENOTHE. Reference Points for Degree Programmes in Occupational Therapy. Bilbao: Universidad de Bilbao, 2008. Available from: <http://www.unideusto.org/ tuningeu/images/stories/Publications/OCCUPATIONAL_THERAPY_FOR_WEBSITE.pdf>.Access on: 1 july 2019.

CRAIK, C. British Journal of Occupational Therapy: 80 years of reflecting and influencing occupational therapy. Brazilian Journal of Occupational Therapy, São Carlos, v. 26, n. 4, p. 721-722, 2018.

CRUZ, D. M. C. Historical milestones of occupational therapy research in Brazil. British Journal of Occupational Therapy, London, p. 1-3, 2019. No prelo. https://doi.org/10.1177/0308022618820270.

DIRETTE, D. P. Occupational therapy: celebrating 100 years of art and science. The Open Journal of Occupational Therapy, Michigan, v. 5, n. 2, p. 1-4, 2017.

DRUMMOND, A. F; CRUZ, D. M. C. History of Occupational Therapy in Brazil: inequalities, advances, and challenges. Annals of International Occupational Therapy, Thorofare, v. 1, n. 2, p. 103-112, 2018.

GALHEIGO, S. M. et al. Knowledge production, perspectives and theoretical-practical references in Brazilian occupational therapy: milestones and tendencies in a timeline. Cadernos Brasileiros de Terapia Ocupacional, São Carlos, v. 26, n. 4, p. 723-738, 2018.

GIDDENS, A. Sociology. Cambridge: Polity Press, 2001.

LEE, K. Globalisation: what is it and how does it affect health? Medical Journal of Australia, Sydney, v. 80, n. 4, p. 156-158, 2004.

LOPES, R. E.; CRUZ, D. M. C.; MALFITANO, A. P. S. Estamos no nosso melhor momento. Cadernos Brasileiros de Terapia Ocupacional, São Carlos, v. 25, n. 3, p. 447-448, 2017.

MANGIA, E. H.; BREGALDA, M. M. Internationalization and the challenges of the World Federation of Occupational Therapists (WFOT) Minimum Standards for the Education of Occupational Therapists. Revista de Terapia Ocupacional da Universidade de São Paulo, São Paulo, v. 29, n. 3, p. i-ii, 2018.

MUNGUBA, M. C.; MALFITANO, A. P. S.; LOPES, R. E. Debate over the "social question" in occupational therapy: an integrative review. Cadernos Brasileiros de Terapia Ocupacional, São Carlos, v. 26, n. 4, p. 892-903, 2018.

PATTISON, M. Message from the president: global health policy. World Federation of Occupational Therapists Bulletin, Oxfordshire, v. 74, n. 1, p. 3-7, 2018.

ROGERS, A. T. et al. Higher hospital spending on occupational therapy is associated with lower readmission rates. Medical Care Research and Review, New York, v. 74, n. 6, p. 668-686, 2017.

ROYAL COLLEGE OF OCCUPATIONAL THERAPISTS - RCOT. Research and development review. Available from: <https://www.rcot.co.uk/practice-resources/research-resources/research-and-development-review>. Access on: 4 nov. 2019.

WESCOTT, L.; WHITCOMBE, S. W. Globalisation and occupational therapy: poles apart?. British Journal of Occupational Therapy, London, v. 66, n. 7, p. 328-330, 2003.

WORLD FEDERATION OF OCCUPATIONAL THERAPISTS - WFOT. Education standards. Available from: $<$ https://www.wfot.org/assets/resources/COPYRIGHTED-World-Federation-of-Occupational-Therapists-MinimumStandards-for-the-Education-of-Occupational-Therapists-2016a.pdf>. Access on: 4 nov. $2018 \mathrm{a}$.

WORLD FEDERATION OF OCCUPATIONAL THERAPISTS - WFOT. Fundamental beliefs. Available from: <http://www.wfot.org>. Access on: 4 nov. 2018b.

WORLD HEALTH ORGANISATION - WHO. Global strategy and action plan on ageing and health (2016-2020). Available from: <http://www.who.int/ageing/GSAP-Summary-EN.pdf?ua=1>. Access on: 1 july 2019. 